\title{
ハロボレーション反応と光れを利用した 有機合成
}

鈴木章*原正 治*

\section{Haloboration and Its Application to Organic Synthesis.}

\begin{abstract}
Akira SUZUKI* and Shoji HARA*
Although the haloboration reaction would be considered to provide useful application to organic synthesis, the reaction has not adequately developed for such purposes.

Most recently, we found that $\mathrm{B}$-halo-9-borabicyclo $[3,3,1]$ nonane $(\mathrm{B}-\mathrm{X}-9-\mathrm{BBN}, \mathrm{X}=\mathrm{Br}$ or $\mathrm{I})$ reacts with 1 -alkynes stereo-, regio-, and chemoselectively. For example, the bromoboration of 1alkynes with $\mathrm{B}-\mathrm{Br}-9-\mathrm{BBN}$ is very facile and complete within a few hours via a cis addition of the $\mathrm{Br}-\mathrm{B}$ bond to the terminal triple bond. Such a reaction was confirmed to occur only at terminal triple bonds, but not at internal triple bonds, terminal and internal double bonds.

The sequential treatments of the haloboration products afford convenient methodologies of obtaining 2-halo-1-alkenes, (Z)-1-alkynyl-2-halo-1-alkenes, $(E)$ - and (Z)-1,2-dihalo-1-alkenes, $(Z)-\delta$-halo- $\gamma, \delta$-unsaturated ketones, $\alpha$-bromoaldehydes, 1,1 -dialkylethenes, 1 -halo-2, 2-dialkylethenes, trisubstituted ethenes and others.
\end{abstract}

\section{1. はじめに}

オルガノボラン（有機ホウ素化合物）の合成法として は，まずハイドロボレーション反応が考えられる。実際 にアルケンやアルキンのハイドロボレーションで得られ るオルガノボランを有機合成に利用する手法は, 反応の 高い選択性などの特長をもち今や欠かすことのできない 有機合成の重要な手段となっている1)。

一方, オルガノボランを得るもう一つの方法として, 八ロボレーション反応も考えられるが，この反応は従来 あまり有機化学者の興味を引くことがなく，八ロボレー ション反応で合成されたオルガノボランを有機合成に利 用したといら報告はほとんどなかった2)。

最近，われわれは八ロボレーション反応を利用した有 機合成に関する研究に取り組み，いくつかの新しい興味 ある知見を得た。本稿ではそれらの仕事を中心にして述 ベることにする。

\section{* 北海道大学工学部応用化学教室}

* Department of Applied Chemistry, Faculty of Engineering, Hokkaido University

\section{2. ハロボレーション反応}

2.1. ハロボレーションに関する既往の研究 無触 媒条件でのハロボレーション反応について最初に詳しい 研究を報告したのは Lappert ら゙) であった。 $\mathrm{BCl}_{3}$ が触 媒の存在下でアセチレンに付加することはそれ以前より 知られていたが，アルケンやジェンとの反応では重合が 優先して起こる3)。Lappert らはノルボルナジェン（1） が $\mathrm{BCl}_{3}$ と $1: 1$ の付加体 (2) をつくることを見い出し た $(\text { 式 } 1)^{4)}$ 。さらに, 種々のアルケン, ポリエン, アル<smiles>CC(Br)(Br)C(C)(C)C1C2CC1C(Br)C2Cl</smiles>

キンなどの不飽和化合物と $\mathrm{BX}_{3}$ との反応を試みたが5), そのなかでアルキン類のハロボレーションが容易に進む ことを明らかにしだ（式 2)。その後 Blackborowによ

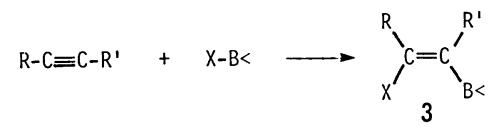

り1-アルキンに対するハロボレーション反応の立体化 
学が詳しく調べられた結果, 低温 $\left(-80^{\circ} \mathrm{C}\right)$ で得られる 付加体を重水素化酢酸で処理すると主として 5 が得られ ることをNMR スペクトルより決定した7)。これにより， $\mathrm{BX}_{3}$ を用いる低温での八ロボレーション反応ではアルキ ンの末端三重結合に対し, B-X 結合が cis-付加するこ とが確かめられた (式 3$)^{7 \mathrm{ce}}$ 。

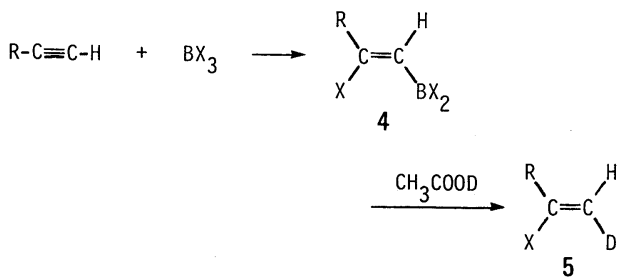

2.2. B-halo-9-borabicycle $[3,3,1]$ nonane (BX-9-BBN) 八ロボレーション反応を有機合成に利用 するためには，高い立体および位置選択性が望まれる。 一方，八ロボレーション付加体（たとえば 4) にはホ ウ素と八ロゲンとの 2 つの官能基があり，これらはいず れも他の置換基に換えられるので有機合成の有用な中間 体として利用できる可能性をもっている。以上の理由で われわれは八ロボレーション反応の検討を行うことを計 画した。

まずハロボレーション試薬として Blackborow の報 告した $\mathrm{BX}_{3}$ の代りに $\mathrm{B}-\mathrm{X}-9-\mathrm{BBN}$ を用いることを試 みた。その理由は, (1) $\mathrm{BX}_{3}$ の場合には 1-アルキンの 複数モルと反応する可能性があること,（2）立体障害 の大きい置換基をもったハロボレーション試薬を用いる ことにより反応の選択性を上げようとしたこと，および (3) B-X-9-BBN の簡便合成法が Brown らによって すでに報告されていたことなどのためである。

すなわち, Brown らはブロモボランジメチルスルフ イド錯体（6）を使ってハイドロボレーションを行うと, 種々のハロボランが容易に合成できることを報告 ${ }^{8)} し て$ いた。われわれはそのなかで, シクロオクタジェンから つくられる B-bromo-9-borabicyclo [3, 3, 1] nonane (B-Br-9-BBN と略記) のジメチルスルフィド錯体 $(7)^{9)}$ をハロボレーション試薬として用いてみることに した（式 4)。しかし予想に反し 7 は 1-アルキン類とは

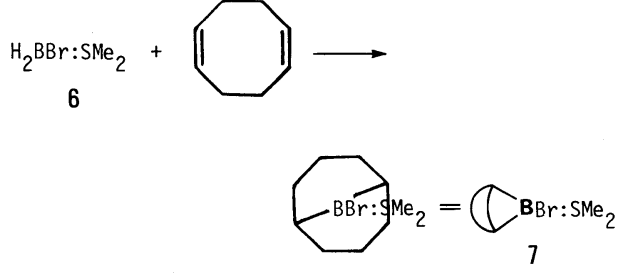

全く反応せず，八ロボレーションに利用するには７から ジメチルスルフィドをはずした 8 を用いなければならな いことがわかった（式 5 )。

$$
7+\mathrm{BBr}_{3} \longrightarrow \overbrace{8}^{\mathrm{BBr}}+\mathrm{BBr}_{3}: \mathrm{SMe}_{2}
$$

8 は 1-アルキンと容易に反応し, その後酢酸でプロ トン化すると対応する 2-ブロモ-1-アルケン（9）が得 られた $(\text { 式 } 6)^{10)}$ 。反応はへキサン, 塩化メチレンのよ

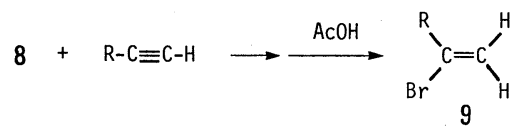

らな非極性溶媒中で収率よく進行するが, エーテル, THF のような極性溶媒中では全く起こらない。この点 はエーテル系の極性溶媒中で反応が促進されるハイドロ ボレーションとは対照的である11;。B-Br-9-BBNによ る反応は非常に位置選択性が高く (99\% 以上), 異性体 の 1-ブロモ-1-アルケンはほとんど生成しない。

次にこの反応の立体化学を調べる目的で（式 7）の実 験を行い, 重水素化物の立体化学を NMR スペクトルに

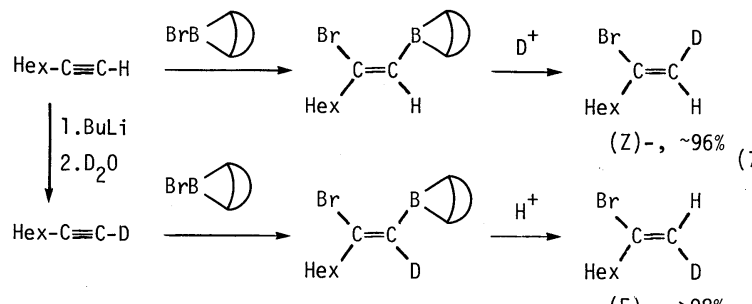

(E)-, $>98 \%$

より決定した。この結果から $\mathrm{B}-\mathrm{Br}-9-\mathrm{BBN}$ が立体選 択的に三重結合に対しマルコニコフ型 $c i s-$ 付加してい ることが確かめられた。またこの試薬はすぐれた官能基 選択性をもち, 系内に内部アルキンや末端あるいは内部 アルケンが存在しても，選択的に 1-アルキンのみが反 応する (式 8 )。さらに，エステル，フェニル基，八ロ

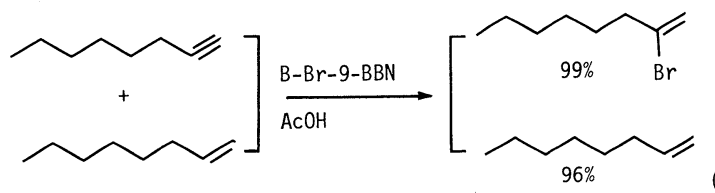


Table 1 Synthesis of 2-bromo- and 2-iodo-1-alkenes (Eqs. 6 and 10).

\begin{tabular}{|c|c|c|c|c|}
\hline Alkyne & $\begin{array}{c}\mathrm{B}-\mathrm{X}-9-\mathrm{BBN} \\
\mathrm{X}\end{array}$ & Product & $\begin{array}{c}\text { Yield }^{a)} \\
(\%)\end{array}$ & $\begin{array}{l}\text { Regioselec- } \\
\text { tivity (\%) }\end{array}$ \\
\hline 1-Hexyne & $\mathrm{Br}$ & 2-Bromo-1-hexene & 99 & 99 \\
\hline 1-Hexyne & I & 2 -Iodo-1-hexene & 100 & 99 \\
\hline 1-Octyne & $\mathrm{Br}$ & 2 -Bromo-1-octene & 95 & 99 \\
\hline 1-Octyne & I & 2 -Iodo-1-octene & 100 & 99 \\
\hline 1-Decyne & $\mathrm{Br}$ & 2-Bromo-1-decene & (88) & 99 \\
\hline 1-Decyne & I & 2 -Iodo-1-decene & $100(83)$ & 99 \\
\hline Phenylethyne & $\mathrm{Br}$ & $\alpha$-Bromostyrene & 95 & 99 \\
\hline Phenylethyne & $\mathrm{I}$ & $\alpha$-Iodostyrene & (85) & 99 \\
\hline 1,6-Heptadiyne & $\mathrm{Br}$ & 2,6-Dibromo-1,6-heptadiene & $(82)$ & 98 \\
\hline 1,6-Heptadiyne & I & 2,6-Diiodo-1,6-heptadiene & (80) & 98 \\
\hline$\Longrightarrow \mathrm{C} \equiv \mathrm{CH}$ & $\mathrm{Br}$ & & $81(65)$ & 98 \\
\hline Cyclohexylethyne & $\mathrm{Br}$ & 1-Bromo-1-cyclohexylethene & $93(80)$ & 99 \\
\hline Cyclohexylethyne & I & 1-Iodo-1-cyclohexylethene & 94 & 99 \\
\hline $\mathrm{HC} \equiv \mathrm{C}\left(\mathrm{CH}_{2}\right)_{8} \mathrm{COOMe}$ & $\mathrm{Br}$ & $\mathrm{H}_{2} \mathrm{C}=\mathrm{CBr}\left(\mathrm{CH}_{2}\right)_{8} \mathrm{COOMe}$ & (88) & 99 \\
\hline Propargyl bromide & $\mathrm{Br}$ & 2,3 -Dibromo-1-propene & 90 & 98 \\
\hline Propargyl bromide & $\mathrm{I}$ & 3-Bromo-2-iodo-1-propene & 88 & 98 \\
\hline $\mathrm{HC} \equiv \mathrm{C}\left(\mathrm{CH}_{2}\right)_{3} \mathrm{OAc}$ & $\mathrm{Br}$ & $\mathrm{H}_{2} \mathrm{C}=\mathrm{CBr}\left(\mathrm{CH}_{2}\right)_{3} \mathrm{OAc}$ & 94 & 99 \\
\hline
\end{tabular}

a) Glpc yield based on the alkyne used. The numbers in parentheses are isolated yields.

ゲンなどの官能基が分子内にあっても $\mathrm{B}-\mathrm{Br}-9-\mathrm{BBN}$ によるブロモボレーションは影響を受けないことが確か められた（表 1 )。

山本ら ${ }^{12)}$ は，この反応を天然物 (一)-ipsenol (12)の 不斉合成に利用した (式 9 )。すなおち $\mathrm{B}-\mathrm{Br}-9-\mathrm{BBN}$ は10から 11 への変換で水酸基や光学純度に影響を与 えることなく収率よく11を与えている。

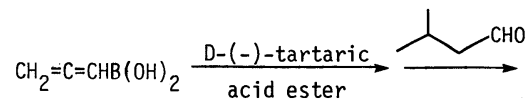

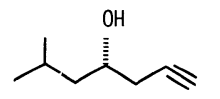

$1099 \%$ ee

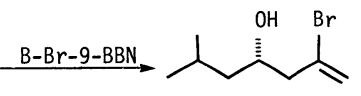

11

yield, $92 \%$

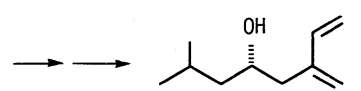

$12 \sim 100 \%$ ee

B-Br-9-BBN はより簡便に 9-borabicyclo $[3,3,1]$ nonane (9-BBN) と臭素との反応でも合成できる ${ }^{13)}$ 。 また Aldrich 社から塩化メチレン溶液として市販され ている。
次に，われわれは $\mathrm{B}-\mathrm{Cl}-9-\mathrm{BBN}(13)^{13)}$ と $\mathrm{B}-\mathrm{I}-$ 9-BBN (14) ${ }^{13)}$ を使って1-アルキンのクロロボレーシ ヨンとヨウドボレーション反応を検討した。B-I-9-BBN は B-Br-9-BBN と同様 1-アルキンと反応し, プロト ン化すると 2-ヨウド-1-アルケン (15) を与えるが（表 1)，B-Cl-9-BBN は同じ反応条件下で 1-アルキンと 全〈反応しなかった（式 10 )。反応性は B-I-9-BBN> $\mathrm{B}-\mathrm{Br}-9-\mathrm{BBN}>\mathrm{B}-\mathrm{Cl}-9-\mathrm{BBN}$ の順であることがわか った。

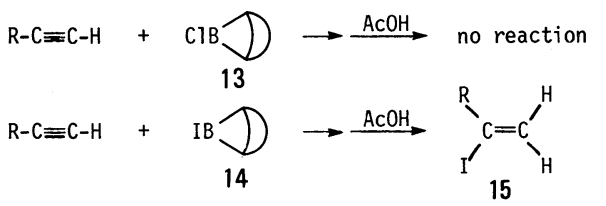

2.3. B-X-9-BBN を用いる1-ハロ-1-アルキンの ハロボレーション反応 ${ }^{14)} 1$ 1-ハロ-1-アルキンは八ロ ボレーションに対し異なった挙動を示す。たとえば 1ハロ-1-アルキンは B-Br-9-BBN と非常に緩慢に反応 する。室温で数日反応させた後にプロトン化して得られ る 1,2-ジハロ-1-アルケン (16) は $Z$-体 (16a) と $E$ 体 (16 b) の混合物であり，しかも三重結合に対し BBr-9-BBN が trans-付加して得られたとみられるZ- 


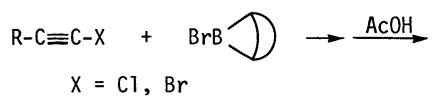<smiles></smiles>

体（16a）が主生成物として与えられた（式 11）。

B-Br-9-BBN の代りに反応性の高いヘキシルジブロ モボラン (17) を用いると反応は数時間で終了し, 生成 物は逆に $E$-体 (16 b) が主に得られた（式 12$)$ 。このよ

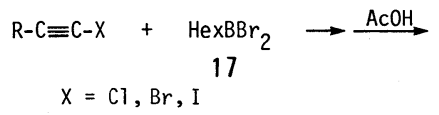

$\underset{\text { minor }}{16 a}+16 b$

うに 1-ハロ-1-アルキンと異なったハロボレーション 試薬を用いて反応すると $(E)$-あるいは $(Z)-1,2$ - ジ八 ロー1-アルケン (16) をかなり高い選択性で合成するこ とができる（表 2 ）。この方法で得られる生成物の立体 選択性は必ずしも充分ではないが $Z$-体については後記 するようにもっと選択的な合成法がみつかった (4.2.)。

2.4. B-X-9-BBN を用いるアレン類のハロボレー ション反応 ${ }^{15)}$ アレン類の八ロボレーションも反応速 度が遅く, ヘキサン溶液中で $\mathrm{B}-\mathrm{I}-9-\mathrm{BBN}$ と室温で 1 日，または還流下で 1 時間反応させる必要がある。プロ トン化して得られる生成物は 2 -ヨウド-1-アルケン (17) と 2-ヨウド-2-アルケン (18) の混合物である が (式 13 ), 両者の比は用いるアレン類の構造に影響さ れる。直鎖の末端アレンでは 17 がかなり選択的に得 られるが，置換基がかさ高くなると 18 の割合が増加
Table 3 Synthesis of 2-iodoalkenes from terminal allenes (Eq. 13).

\begin{tabular}{l|c|c}
\hline \multicolumn{1}{c|}{ Allene } & $\begin{array}{c}\text { Yield }^{\mathrm{a})} \\
(\%)\end{array}$ & $\begin{array}{c}\text { Product distribution } \\
(\%) \\
\mathbf{1 7}: 18\end{array}$ \\
\hline 1,2 - Heptadiene & $(76)$ & $94: 6$ \\
$1,2-$ Nonadiene & 65 & $90: 10$ \\
$1,2-$ Undecadiene & 65 & $90: 10$ \\
$\mathrm{CH}_{\mathrm{CH}=\mathrm{CH}_{2}}$ & 68 & $56: 44$ \\
$\mathrm{C}_{\mathrm{C}=\mathrm{CH}_{2}}$ & 55 & $79: 21$ \\
$\mathrm{CH}_{2} \mathrm{CH}_{2} \mathrm{CH=C= \textrm {CH } _ { 2 }}$ & 73 & $94: 6$ \\
\hline
\end{tabular}

a) Isolated yields based on the allenes used, and glpc yield in a parenthesis.

b) By glpc analysis.

$$
\begin{aligned}
& \underset{\mathrm{R}^{\prime}}{\mathrm{R}=\mathrm{C}=\mathrm{CH}_{2}}+\mathrm{IB} \bigcirc \rightarrow \stackrel{\mathrm{ACOH}}{\longrightarrow}
\end{aligned}
$$

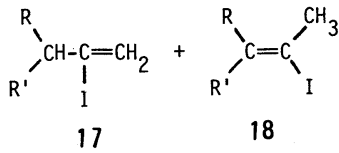

する（表 3 )。

3. ハロボレーション付加体を用いるハロゲン化 二置換アルケニルの選択的合成

3.1. リチウムアセチリドとの反応16) B-X-9BBN による1-アルキンの八ロボレーション反応は立体 および位置選択的に進むことが確かめられたので, 付加 体 (19) のホウ素を他の置換基に換えることを検討した (式 14)。

Table 2 Stereoselective synthesis of (E)- and (Z)-1,2-dihalo-1-alkenes (Eqs. 11 and 12).

\begin{tabular}{l|l|c|c|c}
\hline Haloalkyne & Haloborane & $\begin{array}{c}\text { Reaction time } \\
(\mathrm{h})\end{array}$ & $\begin{array}{c}\text { Yield }^{\text {a) }} \\
(\%)\end{array}$ & $\begin{array}{c}\text { Product ratio } \\
Z: E\end{array}$ \\
\hline $\mathrm{BuC} \equiv \mathrm{CCl}$ & $\mathrm{B}-\mathrm{Br}-9-\mathrm{BBN}$ & 72 & $(80)$ & $81: 19$ \\
$\mathrm{BuC} \equiv \mathrm{CCl}$ & $\mathrm{HexBBr}$ & $(83)$ & $28: 72$ \\
$\mathrm{BuC} \equiv \mathrm{CBr}$ & $\mathrm{B}-\mathrm{Br}-9-\mathrm{BBN}$ & 72 & 67 & $82: 18$ \\
$\mathrm{BuC} \equiv \mathrm{CBr}$ & $\mathrm{HexBBr}$ & 2 & 63 & $5: 95$ \\
$\mathrm{HexC} \equiv \mathrm{CCl}$ & $\mathrm{B}-\mathrm{Br}_{2}-\mathrm{BBN}$ & 96 & 60 & $92: 8$ \\
$\mathrm{HexC} \equiv \mathrm{CCl}$ & $\mathrm{HexBBr}$ & 60 & $28: 72$ \\
$\mathrm{BuC} \equiv \mathrm{CI}$ & $\mathrm{HexBBr}_{2}$ & 2 & $(66)$ & $20: 80$ \\
\hline
\end{tabular}

a) Isolated yields based on the haloalkynes employed. The numbers in parentheses are glpc yields. 


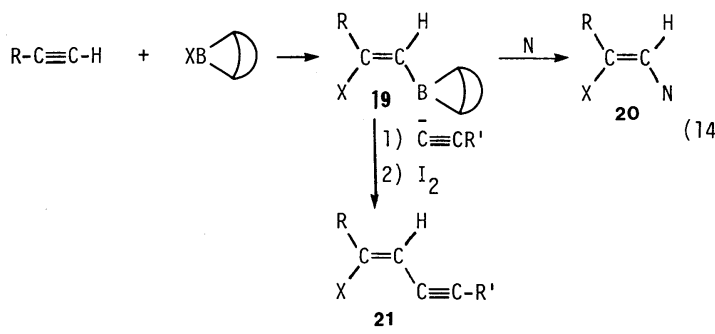

ハロゲン化二置換アルケニルの選択的合成法としては, 1-アルキンのカルボメタレーションを利用する方法 ${ }^{17)}$ が知られているが，この方法では 20 のような置換形式 のハロゲン化アルケニルは合成できない。

付加体 (19) は塩基にも酸にも弱いので, 置換反応は 温和な条件の下で行わなければならない。従って比較的 弱い親核剤であるリチウムアセチリドとの反応を低温で 検討してみた。すなわち 1 -アルキンを八ロボレーショ ンした後, $-78{ }^{\circ} \mathrm{C}$ でリチウムアセチリドと反応させ, さらにヨウ素を作用させたところ，ホウ素がアルキニル 基で置換された 21 が得られた（式 14 ）。反応はアルケ ニルボラン (19)の立体配置を完全に保持したままで進 み，Z-体が $98 \%$ 以上の選択性で得られた。また競争的 に起こるシクロオクタン環の開裂転位によってできる副 生成物の収率は低く, 反応終了後過酸化水素酸化により アルコールに変えることによって簡単に 21 と分離する ことができる（表 4 ）。

Table 4 Synthesis of (Z)-1-alkynyl-2-halo-1alkenes from 1-alkynes (Eq. 14).

\begin{tabular}{l|l|l|l|c}
\hline \multicolumn{1}{c|}{$\mathrm{R}$} & \multicolumn{1}{|c|}{$\mathrm{R}^{\prime}$} & $\mathrm{X}$ & $\begin{array}{c}\text { Yield } \\
(\%)\end{array}$ & $\begin{array}{c}\text { Selectivity } \\
(\%)\end{array}$ \\
\hline Hexyl & Butyl & $\mathrm{Br}$ & 64 & 98 \\
Hexyl & Butyl & $\mathrm{I}$ & 74 & 99 \\
B- & Butyl & $\mathrm{Br}$ & 62 & 98 \\
Butyl & Hexyl & $\mathrm{Br}$ & 66 & 98 \\
Butyl & Butyl & $\mathrm{Br}$ & 66 & 98 \\
Butyl & Butyl & $\mathrm{I}$ & $72(83)$ & 98 \\
Hexyl & Ethyl & $\mathrm{Br}$ & 65 & 99 \\
Hexyl & Ethyl & $\mathrm{I}$ & 70 & 98 \\
Ethyl & Hexyl & $\mathrm{Br}$ & 63 & 98 \\
Ethyl & Hexyl & $\mathrm{I}$ & 67 & 98 \\
Phenyl & Butyl & $\mathrm{Br}$ & 53 & 99 \\
Hexyl & PhOCH $_{2-}$ & $\mathrm{Br}$ & 62 & 98 \\
Hexyl & PhOCH $_{2-}$ & $\mathrm{I}$ & $(73)$ & 98 \\
Cyclohexyl & Butyl & $\mathrm{I}$ & 72 & 98 \\
\hline
\end{tabular}

a) Isolated yields based on alkynes used. In parentheses, glpc yields.
この反応は次のような機構で進行すると考えられる。 すなわち 19 とリチウムアセチリドからつくられるボレ ート錯体 (22) がヨウ素と反応し, 環状ヨウドニウム中 間体の生成とそれに続くアルケニル基の転位を経て 23 となる。最後にヨウドボランが脱離して 21 を生成する (式 15 )。

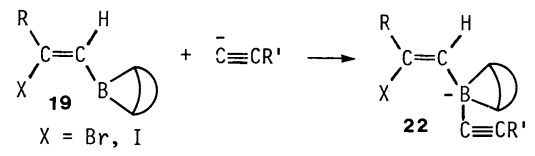
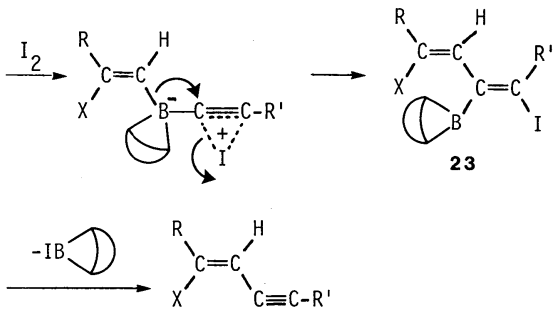

21

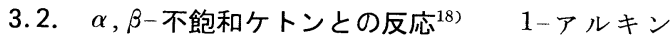
を 9-BBN (9-borabicyclo [3,3,1] nonane) でハイド ロボレーションして得られる B-アルケニル-9-BBN は THF 溶液中メチルビニルケトンに対し，1,4-付加する ことが知られているが19)，ほとんど同じ構造をもつ 19 は同様の条件下ではメチルビニルケトンとは反応しない。 反応溶媒を THF からペンタンに代え，B-X-9-BBN を過剩に用いると反応が速やかに進み，生成物として目 的の 1,4-付加体 (24) がさらに別のメチルビニルケトン とアルドール縮合してできる 25 を主に与えることが明 らかとなった（式 16 )。一方，25を単離することなく，

19
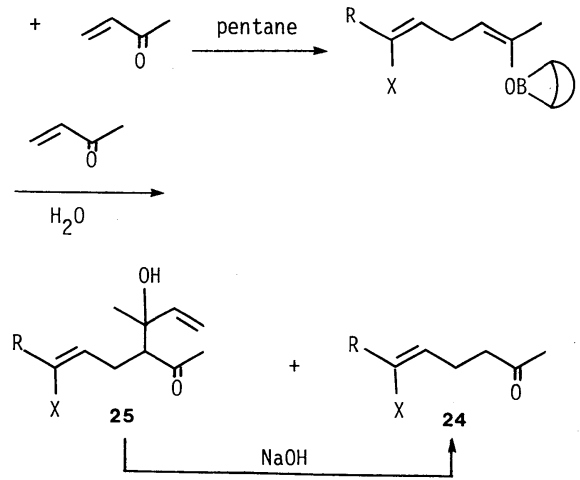

アルカリと処理すると容易に逆アルドール反応が起こり, 目的の 24 を得ることができた（式 16 )。24 の立体配置 は $Z$ であり, 反応が完全に 19 の立体化学を保持したま 
Table 5 Synthesis of $(Z)-\delta$-Halo- $\gamma, \delta$-unsaturated ketones (Eq. 16).

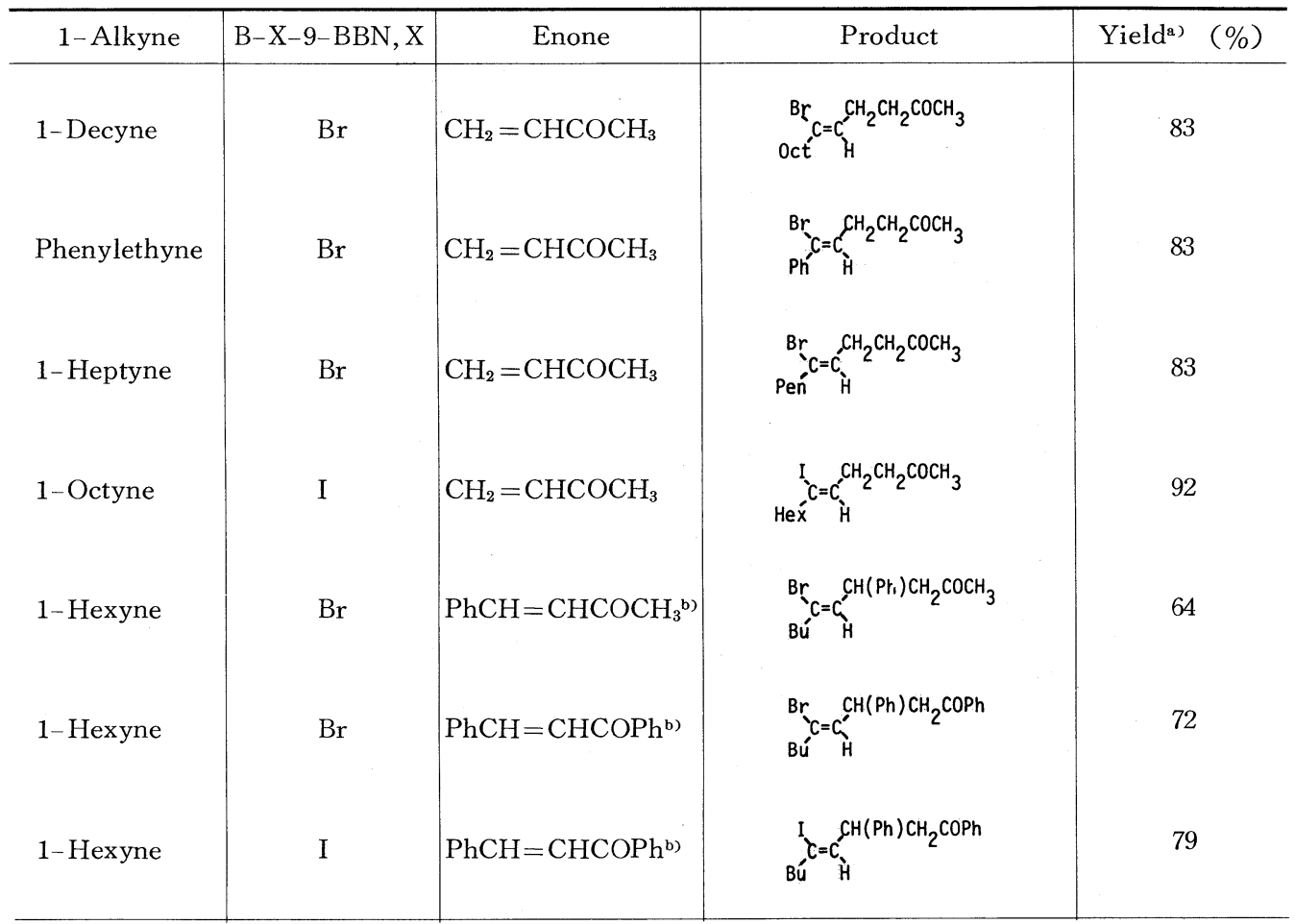

a) Isolated yields based on the 1-alkynes used.

b) Without treatment by alkali.

ま進むことを示している。またメチルビニルケトン以外 の不飽和ケトンを使った場合には，アルドール縮合体は 得られず, 直接 1,4-付加体が得られた（表 5 )。

メチルビニルケトンの代りに 2-トリメチルシリル-1ブテンー3-オン（26）を用いると, やはりアルドール縮 合を起こすことなく直接 1,4 - 付加体 (24) が得られる。 この方法は塩基や熱に弱い官能基が分子内に存在する場 合に有効である（式 17 )。

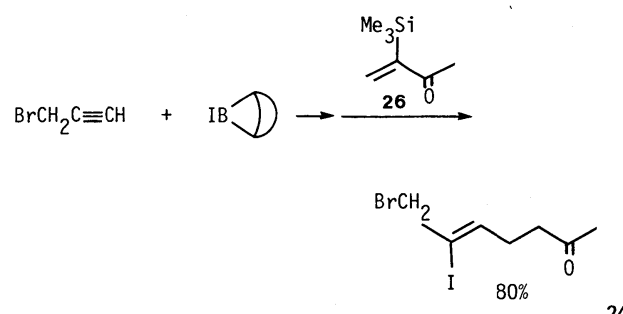

われわれはこの反応を利用して, sulcatol (27), transgeranyl acetone (28), trans-nerolidol (29)などのテ ルペン類の合成を試み, 良好な結果を得た ${ }^{20)}$ 。

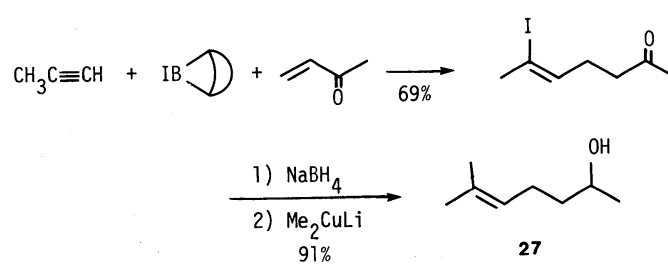

$\widehat{N}+\mathrm{IBD}^{\mathrm{N}}$

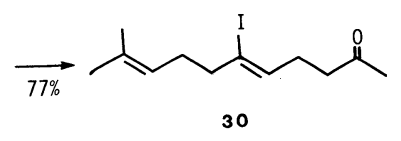

30

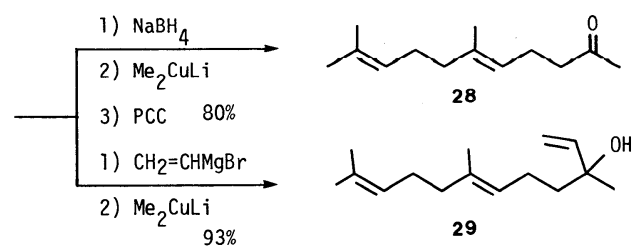




\section{B-X-9-BBN 以外のハロボレーション試薬 を用いた反応}

4.1. $\alpha$-ブロモアルデヒド合成 $\mathrm{BBr}_{3}$ を用いても

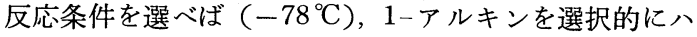
ロボレーションすることができる ${ }^{7 \mathrm{~b})}$ 。 $\mathrm{BCl}_{3}$ は反応性が 低く, $\mathrm{BI}_{3}$ は非常に高価であるため実用的でない。また, ハロボレーション付加体のホウ素基を他の官能基に変換 する場合, B-X-9-BBN のシクロオクタン環は無い方 が都合のよいことがある。たとえば，アルケニルボラン を過酸化水素で酸化するとアルデヒドやケトンとなるこ とが知られているが22)，1-アルキンを B-X-9-BBN で 八ロボレーションして得られる $\beta$ 一ハロアルケニルボラ ン（19）は，酸化条件をいろいろ検討したが，対応する $\alpha$-ハロアルデヒド (31) へ変換することができなかった。

一方, 八ロボレーション試薬として $\mathrm{BBr}_{3}$ を使用し, 酸化時の $\mathrm{pH}$ を調節することによって目的とするブロモ アルデヒド (31) を得ることができることを見い出した （式 18，表 6 )。

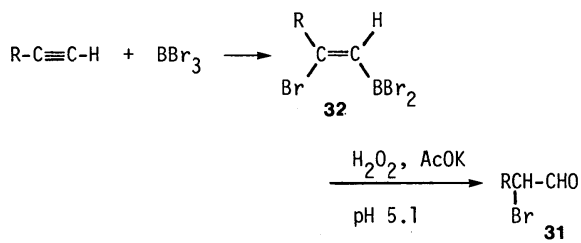

この反応では $\mathrm{BBr}_{3}$ に対して 2 当量の 1 -アルキンを 利用できるが， 2 当量以上の $1-$ アルキンを用いてもブ ロモアルデヒドの通算收率は向上しない。また $\mathrm{BBr}_{3}$ は B-Br-9-BBN に比べて反応性が高いが，溶媒としてト

$\mathrm{HC} \equiv \mathrm{C}\left(\mathrm{CH}_{2}\right)_{8} \mathrm{COOMe} \underset{\text { Toluene }}{\stackrel{\mathrm{BBr}_{3}}{\longrightarrow}} \stackrel{\mathrm{H}_{2} \mathrm{O}_{2}, \mathrm{AcOK}}{\longrightarrow}$

$$
\underset{\mathrm{OHC}-\mathrm{CH}\left(\mathrm{CH}_{2}\right)_{8} \mathrm{COOMe}}{\mathrm{Br}}
$$

ルエンを用いて反応性を下げることにより，エステルの ような官能基をもったアルキン類を反応に利用すること もできる（式 $19 ） 。$

4. 2.（Z)-1,2-ジハロ-1-アルケンの合成 ${ }^{23)} \quad \mathrm{BBr}_{3}$ をハロボレーションに用いて得られる $\beta$-ハロアルケニ

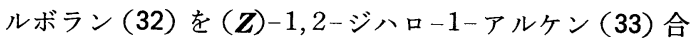
成に利用できる。八ロゲン化の方法としては, Kabalka ら ${ }^{24)}$ の開発したクロラミン Tーハロゲン化ナトリウム酢酸ナトリウムの系が最も良く，いずれの場合にも $95 \%$ 以上の異性体純度で 33 が得られた。この方法は前に述 べた 1-ハロ-1-アルキンのハロボレーションによる 33 の合成法 (2.3) よりも選択性が良い（式 20)。

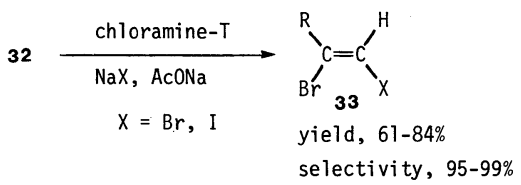

4.3. イソシアネートとの反応25) 32 はイソシア ネートと反応し， $\alpha, \beta$-不飽和- $\beta$-ブロモアミド (34)を 与える（式 21 )。しかしこの場合には 32 の立体化学は 保持されず, 生成物は $E$-体と $Z$-体の混合物となり, また両者の割合は反応温度や立体障害の影響を受ける。

$$
\underset{R=H e x}{\stackrel{P h N C=0}{r . t ., 2 h}}
$$

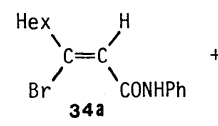<smiles>O=C(Br)/C=C\C(=O)c1ccccc1</smiles>

yield of $34 a+34 b, \quad 71 \%$ ratio of $34 a: 34 b, 17: 83$

4.4. ハロジェン合成 ${ }^{26)} \mathrm{B}-\mathrm{X}-9-\mathrm{BBN}$ や $\mathrm{BBr}_{3}$ 以 外にも，ホウ素ーハロゲン結合をもつ化合物をハロボレ ーション反応に用いることができる ${ }^{2,27)}$ 。一方， ジブロ モボランジメチルスルフィド錯体 $\left(\mathrm{Br}_{2} \mathrm{BH}: \mathrm{SMe}_{2}\right)$ の

Table 6 Synthesis of $\alpha$-bromoaldehydes (Eq. 18).

\begin{tabular}{l|l|c}
\hline \multicolumn{1}{c|}{ 1-Alkyne } & \multicolumn{1}{|c}{ Product } & Yield $^{\text {a) }}(\%)$ \\
\hline $\mathrm{BuC} \equiv \mathrm{CH}$ & $\mathrm{BuCHBrCHO}$ & $65(70)$ \\
$\mathrm{PenC} \equiv \mathrm{CH}$ & PenCHBrCHO & $65(71)$ \\
$\mathrm{HexC} \equiv \mathrm{CH}$ & $\mathrm{HexCHBrCHO}$ & 68 \\
$\mathrm{OctC} \equiv \mathrm{CH}$ & OctCHBrCHO & 70 \\
$t-\mathrm{BuC} \equiv \mathrm{CH}$ & $t-\mathrm{BuCHBrCHO}$ & 68 \\
$\mathrm{Me}_{2} \mathrm{C}=\mathrm{CH}\left(\mathrm{CH}_{2}\right)_{2} \mathrm{C} \equiv \mathrm{CH}$ & $\mathrm{Me}_{2} \mathrm{C}=\mathrm{CH}\left(\mathrm{CH}_{2}\right)_{2} \mathrm{CHBrCHO}$ & 60 \\
$\mathrm{BrCH}_{2}\left(\mathrm{CH}_{2}\right)_{2} \mathrm{C} \equiv \mathrm{CH}$ & $\mathrm{BrCH}_{2}\left(\mathrm{CH}_{2}\right)_{2} \mathrm{CHBrCHO}$ & 55 \\
\hline
\end{tabular}

a) Isolated yields based on 1-alkynes. Glpc yields in parentheses. 
ハイドロボレーションを利用すると，いろいろな有機基 をもったブロモボランが合成 ${ }^{28)}$ できるので，アルキンを 八イドロボレーションして得られるアルケニルジブロモ ボラン（35）のアルケニル基を利用したハロジェン合成 を検討した。

3-ヘキシンを $\mathrm{Br}_{2} \mathrm{BH}: \mathrm{SMe}_{2}$ で八イドロボレーショ ンし, つづいて $\mathrm{BBr}_{3}$ を作用させ, ジメチルスルフィド をはずして得られるアルケニルブロモボラン（35）を単 離する。次に 35 を用いて1-オクチンを八ロボレーショ

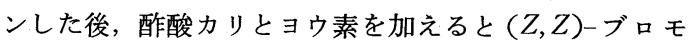
ジェン(36)が得られた（式 22 )。

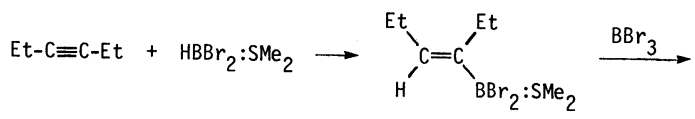<smiles>CC#CCCCCCCCC</smiles>

35

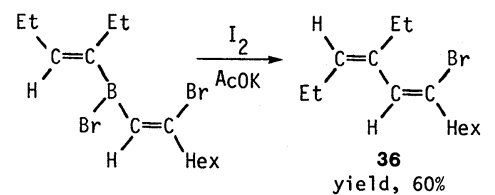

stereoselectivity, $99 \%$

1-アルキンのハイドロボレーションで得られるアルケ ニルジブロモボラン（37）からも，対応するブロモジェ ン(38)が得られるが, 不安定なためそのままプロトン 化してジェン（39）として単離した（式 23 )。

$\mathrm{Bu}-\mathrm{C} \equiv \mathrm{C}-\mathrm{H}+\mathrm{HBBr}_{2}: \mathrm{SMe}_{2} \rightarrow \stackrel{\mathrm{BBr}_{3}}{\longrightarrow}$
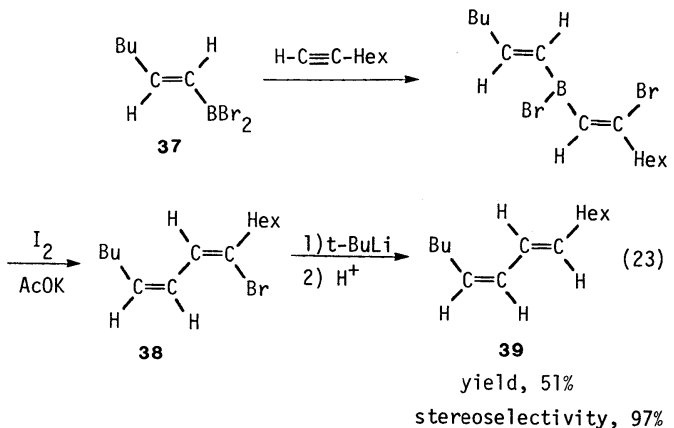

この反応で, ハイドロボレーションと八ロボレーショ ンの反応順を逆にすると, もっと簡単になることがわか った(式 22 と 24 を参照)。まず 2 当量のアルキンを $\mathrm{BBr}_{3}$ でハロボレーションし, 次に残った臭素を還元しながら
別のアルキンのハイドロボレーションを行う。最後に, 酢酸カリウムとヨウ素を反応させると前記の（式 $22 ） の$ 場合と同様 $(Z, Z)$-ブロモジェン (36) が得られる（式 $24)$ 。この方法で反応を行うと, その途中でいずれの中

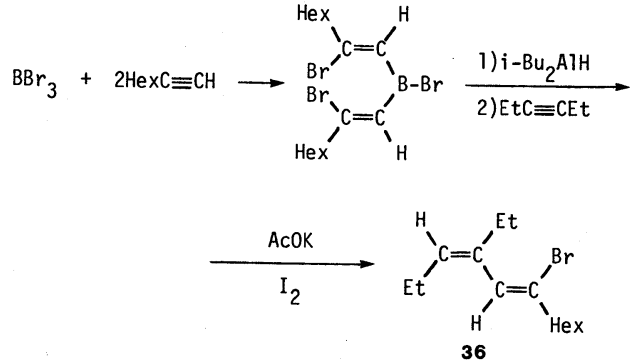

yield, $73 \%$

stereoselectivity, $99 \%$
間体をも単離することなく one-pot の反応で最終生成 物を得ることができる。

生成物（36）では，ハイドロボレーション反応で生成 したアルケニル基の立体化学のみが選択的に逆転してい ることがわかる。その理由については次のように考えて いる。すなわち, 中間体アルケニルボラン (40)にヨウ ドカチオンが攻撃するときに, 臭素の置換していない反 応性の高いアルケニル基のみが（式 25）のよ5に選択

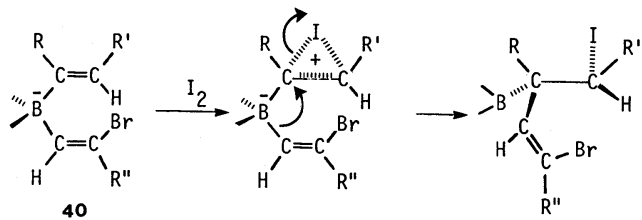<smiles>[R]C(Br)=C([R])/C([R])=C\[CH]</smiles>

的に攻撃を受け, 一方, 攻撃を受けないアルケニル基は その立体配置を保ったまま転位する。最後に IB $<$ が trans-脱離するため生成物 (41) を与える。

二種類の異なるアルキンをハイドロボレーションして 得られるジアルケニルボランを前記と同様の条件下でヨ ウ素と反応させても，選択的なジェン合成を行らことは

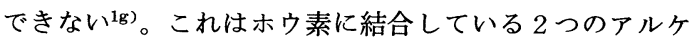
ニル基に対するヨウドカチオンの反応性の差が小さいた 
めである。したがって，立体選択的なジェン合成は八イ ドロボレーションと八ロボレーションの組み合わせによ って初めて可能となる。

式 26 に示すように, 生成物のブロモジェン

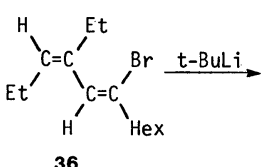
36

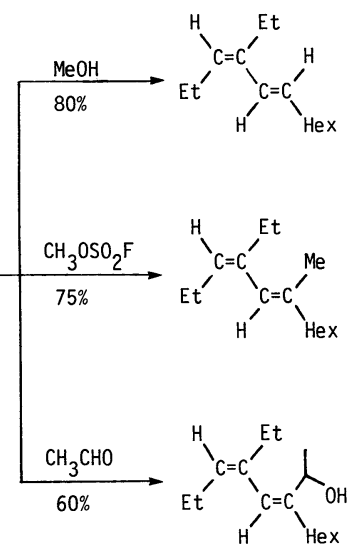

は, リチオ化した後各種の親電子剤と反応させ, 種々の 誘導体に変換することができる。またクロロアルキンか ら出発して得られるジ八ロジェン (42) は, 分子内アル キル化により環化生成物（43）を与える（式 27 )。

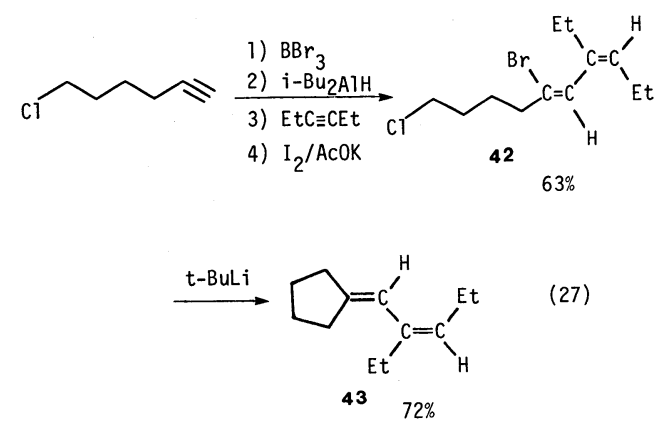

4.5. 三置換アルケンの選択的な直接合成 ${ }^{29}$ 前項 までに，八ロボレーション付加体 (44)のうち八ロゲン を残したままホウ素置換基を他の官能基に換えることを 述べた。このようにして得られるハロゲン化アルケニル （45）から三置換アルケン（46）を選択的に合成できるが, 一方，44のホウ素部分を残して，八ロゲンを有機基に 置換できれば，二置換のアルケニルボラン (47) が得ら れるはずである。47 は八イドロボレーション反応では得 られない構造をもつアルケニルボランであり, 次に三置換 アルケン（46）の合成に利用できるであろう（式 $28 ） 。$

$\mathrm{BBr}_{3}$ で 1-アルキンを八ロボレーションして得られる 付加体 (32) をパラジゥム触媒存在下にアルキル亜鉛化

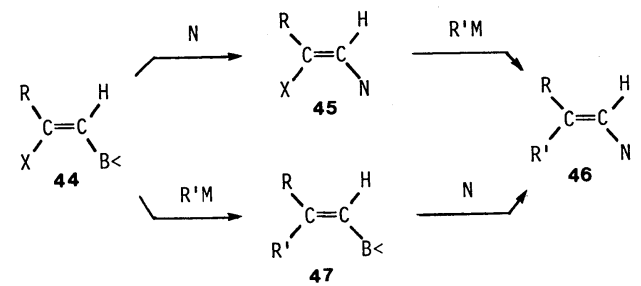

合物と反応させると，アルキル化が順調に進行すること がわかった。その後酢酸でプロトン化すると二置換アル ケン (48) が得られた (式 29 )。この場合 B-X-9-BBN<smiles>[R]/C(Br)=C\Br</smiles>

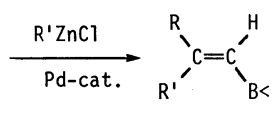

32

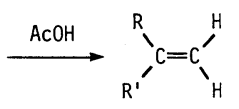

48

をハロボレーション試薬として用いて得られる付加体で は良好な結果を与えない。

この反応は形式的にはアルキンのカルボメタレーショ ン反応と等価であるが，従来のカルボメタレーション17) では導入できなかった $\mathrm{sp} や \mathrm{sp}^{2}$ 炭素の導入も可能であ る点は注目に価する（表7）。

われわれはこの反応を利用してテルペン類天然物であ る myrcene (49), dehydro- $\alpha$-curcumene (50)の合成 を行った（式 $30 ） 。$
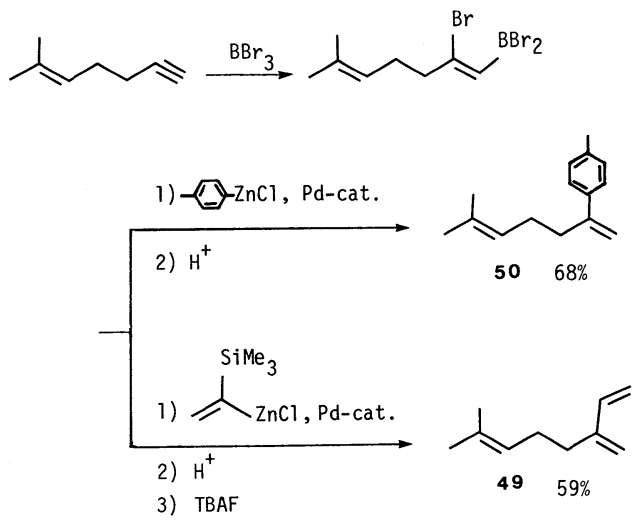

アルキル化反応時に, ホウ素-炭素結合が切断されて いないことは，アルキル化につづいてハロゲン化を行う

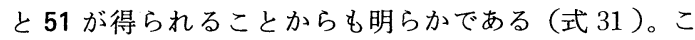
の反応は立体選択的な二置換八ロゲン化アルケニル(51) の合成法として有効である（表 8 ）。 
Table 7 Synthesis of 1,1-dialkylethenes (Eq. 29).

\begin{tabular}{|c|c|c|c|}
\hline $\mathrm{RC} \equiv \mathrm{CH}, \mathrm{R}$ & $\mathrm{R}^{\prime} \mathrm{ZnCl}, \mathrm{R}^{\prime}$ & Product & Yield $(\%)$ \\
\hline Hex & $\mathrm{Bu}$ & & 70 \\
\hline Oct & $\mathrm{Me}$ & & 50 \\
\hline $\mathrm{Bu}$ & Phenyl & & 71 \\
\hline Oct & $\mathrm{Me}_{3} \mathrm{SiCH}_{2}$ & & $92^{b)}$ \\
\hline Oct & $\mathrm{Me}_{3} \mathrm{SiCH}_{2}$ & $\begin{array}{l}\mathrm{Me}_{3} \mathrm{SiCH}_{2}{ }_{\mathrm{C}}=\mathrm{CH}_{2} \\
\mathrm{Oct}^{\mathrm{C}}\end{array}$ & (89) \\
\hline Oct & $\mathrm{CH}_{2}=\mathrm{C}^{\prime \mathrm{SiMe}_{3}}$ & & (78) \\
\hline Hex & $\mathrm{BuC} \equiv \mathrm{C}$ & & (61) \\
\hline
\end{tabular}

a) Glpc yields based on 1-alkynes (isolated yields).

b) $\mathrm{A} \mathrm{SiMe}_{3}$ group was eliminated under the reaction conditions.

Table 8 Synthesis of 1-halo-2,2-dialkylethenes (Eq. 31).

\begin{tabular}{|c|c|c|c|}
\hline $\mathrm{RC} \equiv \mathrm{CH}, \mathrm{R}$ & $\mathrm{R}^{\prime} \mathrm{ZnCl}, \mathrm{R}^{\prime}$ & Product & Yield $^{a} \quad(\%)$ \\
\hline Hex & $\mathrm{Bu}$ & & 59 \\
\hline $\mathrm{Bu}$ & Hex & & 57 \\
\hline Oct & $\mathrm{Me}$ & & 42 \\
\hline $\mathrm{Bu}$ & $\mathrm{Ph}$ & & 65 \\
\hline Oct & $\mathrm{CH}_{2}=\mathrm{C}^{\prime} \mathrm{SiMe}_{3}$ & & (65) \\
\hline Oct & $\mathrm{CH}_{2}=\mathrm{C}^{\prime} \mathrm{SiMe}_{3}$ & & (60) \\
\hline 心 & $\mathrm{CH}_{2}=\mathrm{C}_{1} \mathrm{SiMe}_{3}$ & & (59) \\
\hline Hex & $\mathrm{BuC} \equiv \mathrm{C}-$ & & (53) \\
\hline
\end{tabular}

a) Glpc yields based on 1-alkynes employed, and isolated yields in parentheses. 
Table 9 Synthesis of trisubstituted alkenes (Eq. 31).

\begin{tabular}{|c|c|c|c|c|}
\hline $\mathrm{RC} \equiv \mathrm{CH}, \mathrm{R}$ & $\mathrm{R}^{\prime} \mathrm{ZnCl}, \mathrm{R}^{\prime}$ & $\mathrm{R}^{\prime \prime} \mathrm{X}$ & Product & Yield $^{a)}(\%)$ \\
\hline Hex & $\mathrm{Bu}$ & $\mathrm{PhI}$ & & 65 \\
\hline Hex & $\mathrm{Ph}$ & $\mathrm{PhI}$ & & 70 \\
\hline Hex & $\mathrm{Me}_{3} \mathrm{SiCH}_{2}$ & $\mathrm{PhI}$ & & 73 \\
\hline Hex & $\mathrm{CH}_{2}=\mathrm{C}_{1}^{-\mathrm{SiMe}_{3}}$ & $\mathrm{PhI}$ & & 73 \\
\hline Hex & $\mathrm{BuC} \equiv \mathrm{C}-$ & $\mathrm{PhI}$ & & 54 \\
\hline Hex & $\mathrm{Bu}$ & $\mathrm{CH}_{2}=\mathrm{CHCH}_{2} \mathrm{Br}$ & & 56 \\
\hline Hex & $\mathrm{CH}_{2}=\mathrm{C}^{-\mathrm{SiMe}_{3}}$ & $\mathrm{CH}_{2}=\mathrm{CHCH}_{2} \mathrm{Br}$ & & 78 \\
\hline Hex & $\mathrm{SiMe}_{3}$ & $\mathrm{CH}_{2}=\mathrm{C}(\mathrm{Me}) \mathrm{CH}_{2} \mathrm{Br}$ & & 67 \\
\hline Hex & $\mathrm{Me}_{3} \mathrm{SiCH}_{2}$ & $\mathrm{PhCH}_{2} \mathrm{Br}$ & & 80 \\
\hline
\end{tabular}

a) Glpc yields based on 1-alkynes.
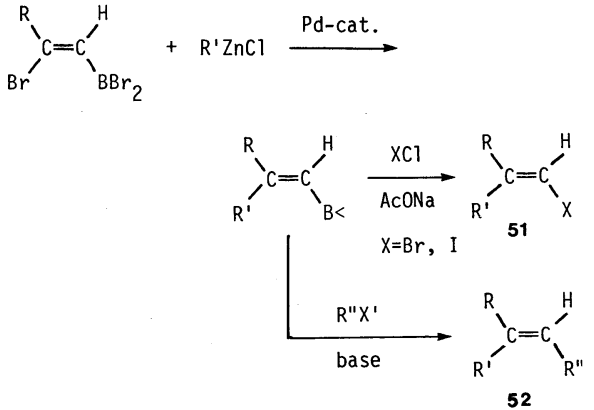

最後に，八ロボレーション付加物を用いて三置換アル ケンの直接合成を試みた。アルケニルボランは適当なパ ラジウム触媒と塩基が存在すると有機ハロゲン化物とク ロスカップリングすることを，われわれは先に報告 ${ }^{30)} し$ た。式 31 に示すようにアルキル塩化亜鉛による $\beta$ 八ロアルケニルボランのアルキル化の段階では, 塩基が 存在しないのでホウ素置換基での反応は起こらない。し かし, 次のステップで塩基と有機ハロゲン化物 $\left(\mathrm{R}^{\prime \prime} \mathrm{X}^{\prime}\right)$ を加えると，ホウ素置換基での反応が進行し，三置換ア ルケン（52）が合成される（式 31 ）。はじめに使用した パラジウム触媒が，二段目のアルキル化でも㗢くので, あらたに触媒を添加する必要はない。この方法は, 従来
のカルボメタル化ーアルキル化反応 ${ }^{17)}$ では合成できない 種々の置換基をもった三置換アルケンの選択的合成法と して有用である（表 9 ）。

\section{5.おわりに}

以上，われわれの研究室で最近行ってきたハロボレー ション反応と，それを利用した有機合成についてまとめ てみた。本文中にも記したように，この分野の研究はま だ緒についたばかりであり，まだまだ未知の点も多く， 一方大きな可能性を残していると考えられる。ハロボレ ーションに関するこの種の総説が公になるのはこの小文 がはじめてと思われるが，有機合成に興味をもたれる方 々に少しでもお役に立つことができれば大きな喜びであ る。

（昭和 59 年 8 月 3 日受理）

$$
\text { 文献 }
$$

1a) H. C. Brown, "Boranes in Organic Chemistry", Cornel Univ. Press, Ithaca, New York, 1972

b) G. M. L. Cragg, "Organoboranes in Organic Synthesis", Dekker, New York, 1973

c) H.C.Brown, "Organic Synthesis via Boranes", Wiley, New York, 1975

d) A.Pelter, K.Smith, "Comprehensive Organic 
Chemistry", Vol.3, Ed., D.N. Jones, Pergamon, Oxford, 1979

e) E. Negishi, "Organometallics in Organic Synthesis", Wiley, New York, 1980

f) A.Suzuki, Acc. Chem. Res., 15, 178 (1982)

g) H.C.Brown, M.Zaidlewicz, E. Negishi, "Comprehensive Organometallic Chemistry", Vol.7, Ed,, G. Wilkinson, Pergamon, Oxford, 1982

h) A.Suzuki, "Topics in Current Chemistry", Vol.112, Ed., K.Hafner et al.. Springer, Heidelberg, 1983

i) B. M. Mikhailov, Yu. N. Bubnov, "Organoboron Compounds in Organic Synthesis", Harwood, Chur, Switzerland, 1984

2a) J.J.Eisch, L. J. Oonsior, J. Organomet. Chem., 8, 53 (1967)

b) F. Joy, M.F. Lappert, B.Prokai, ibid., 5, 506 (1966)

c) J.J.Eisch, H.P.Becker, ibid., 171, 14 (1979)

d) J.J.Eisch, F.Shen, K. Tamao, Heterocycles, 18, 245 (1982)

3) H.R.Arnold, USP, 2,462,589 (1946)

4a) M.F.Lappert, Angew. Chem., 72, 36 (1960)

b) F. Joy, M.F.Lappert, Proc. Chem. Soc., 1960, 353

5) F. Joy, M. F. Lappert, B. Prokai, J. Organomet. Chem., 5, 506 (1966)

6) M.F.Lappert, B.Prokai, ibid., 1, 384 (1964)

7a) J.R. Blackborow, J. Chem. Soc., Perkin II, 1973, 1989

b) J. R. Blackborow, J. Organomet. Chem., 128, 161 (1977)

c）この場合ハロボレーションに対する収率の報告は なされていない。

8a) H C. Brown, N. Ravindran, Inorg. Chem. 16, 2938 (1977)

b) H.C Brown, N. Ravindran, S. U. Kulkarni, J. Org. Chem. 44, 2417 (1979)

9) H.C. Brown, S. U. Kulkarni, J. Org. Chem., 44, 2422 (1979)

10) S.Hara, H. Dojo, S. Takinami. A.Suzuki, Tetrahedron Lett.. 1983, 731

11) H. C. Brown, B. C. Subba Rao, J. Am. Chem. Soc., 78, 5694 (1956)

12) N.Ikeda, I Arai, H. Yamamoto, 私信。

13) H. C. Brown, S. U. Kulkarni, J. Organomet. Chem., 168, 281 (1979)

14) S.Hara, T.Kato, A.Suzuki, Synthesis, 1983, 1005
15) S. Hara, S. Takinami, S. Hyuga, A. Suzuki, Chem. Lett., 1984, 345

16) S. Hara, Y.Satoh, H. Ishiguro, A.Suzuki, Tetrahedron Lett., 1983, 735

17) J.F. Normant, A.Alexakis, Synthesis, 1981, 841

18）原 正治，佐藤嘉高，芹沢裕一，鈴木 章，第 29 回有機金属化学討論会要旨集, p.151 (1982年 10 月浜松)

19) P. Jacob, III, H. C. Brown, J. Am. Chem. Soc., 98, 7832 (1976)

20）佐藤嘉高, 芹沢裕一, 原 正治, 鈴木 章, 日化 北海道支部 1984 冬季研究発表会要旨集, p. 69 （1984 年 2 月札幌）

21）原 正治, 石黒寛子, 鈴木 章, 日本化学会第 47 春季年会要旨集, p. 1092 ( 1983 年 4 月京都)

22) H.C.Brown, G.Zweifel, J.Am. Chem. Soc., 83, 3834 (1961)

23）加藤達夫，原 正治，鈴木 章，日本化学会第 48 秋季年会要旨集, p.947（1983 年 8 月札幌）

24a) G. W. Kabalka, E. E. Goch, J. Org. Chem., 46, 2582 (1981)

b) G. W. Kabalka, K. A. R. Sastry, H.C Hsu, M.D. Hylarides, ibid., 46, 3113 (1981)

c) G. W. Kabalka, K. A R. Sastry, V.Somayaji, Heterocycles, 1982, 157

25) Y.Satoh, H.Serizawa, S. Hara, A.Suzuki, Synth. Commun., 14, 313 (1984)

26a）滝浪 悟, 日向 敏, 原 正治, 鈴木 章, 日本 化学会第 49 春季年会要旨集, p. 1548 （1984 年 4 月東京)

b) 日向 敏, 滝浪 悟, 原 正治, 鈴木 章, 同誌, p. 1549 (1984 年 4 月東京)

27) R. Binnewirtz, H. Kingenberger, R. Welter, P. Paetzold, Chem. Ber., 116, 1271 (1983)

28) H.C Brown, J. B. Campbell, Jr., J. Org. Chem. 45, 389 (1980)

29a）佐藤嘉高, 原 正治, 鈴木 章, 第 30 回有機金 属化学討論会要旨集, p. 127 ( 1983 年 10 月京都)

b) 芹沢裕一, 佐藤嘉高, 原 正治, 鈴木 章, 日本 化学会第 49 春季年会要旨集, p. 1549 （1984 年 4 月東京)

30a) N. Miyaura, K. Yamada, A.Suzuki, Tetrahedron Lett., 1979, 3437

b) N. Miyaura, A. Suzuki, Chem. Commun., 1979, 866

c) N. Miyaura, T. Yano. A.Suzuki, Tetrahedron Lett., 1980, 2865

d) N. Miyaura, H. Suginome, A. Suzuki, ibid., 1981,127 